\title{
ANALISIS KADAR FLAVONOID PADA TEH DAUN LAMUN (Enhalus acoroides) BERDASARKAN TINGKAT KETUAAN DAUN
}

\author{
Harfalien Tehubijuluw $^{1}$, Theopilus Watuguly ${ }^{2}$, P.M.J. Tuapattinaya ${ }^{2}$ \\ ${ }^{1}$ Alumni Program Studi Pendidikan Biologi \\ ${ }^{2}$ Dosen Program Studi Pendidikan Biologi \\ E-mail: theo_watuguly@unpatti.fkip.ac.id
}

\begin{abstract}
Background: Seagrass (Enhalus acoroides) is a flowering plant (Angiospermae) that has fully adapted to life immersed in the sea. Seagrass is also a commodity that has been used by many people both modern and traditional. Traditionally seagrass has been used for compost and fertilizer, cigars and children's toys, made into baskets, some are eaten, and made into fishing nets. Whereas in the modern way is as a filter of waste, food, medicines, materials for paper mills, and sources of chemicals.

Methods: Measurement of flavonoid levels of seagrass leaf tea (Enhalus acoroides) was analyzed using a one-way anava test. This research was conducted on 10-18 July 2018.

Results: The analysis showed that old tea drinks from seagrass leaves (Enhalus acoroides) had high flavonoid levels of $0.1623 \%$ while half-old tea drinks with seagrass leaves had moderate flavonoid levels of $0.1263 \%$.

Conclusion: Young tea drinks using seagrass leaves (Enhalus acoroides) have lower flavonoid levels of $0.0888 \%$.
\end{abstract}

Keywords: Levels of flavonoids, tea, seagrass leaves Enhalus acoroides, leaf aging.

\begin{abstract}
Abstrak
Latar Belakang: Lamun (Enhalus acoroides) adalah tumbuhan berbunga (Angiospermae) yang sudah sepenuhnya menyesuaikan diri hidup terbenam di dalam laut. Lamun juga sebagai komoditi yang sudah banyak dimanfaatkan oleh masyarakat baik secara modern maupun tradisional. Secara tradisional lamun telah dimanfaatkan untuk kompos dan pupuk, cerutu dan mainan anak-anak, dibuat menjadi keranjang, ada yang dimakan, dan dibuat menjadi jaring ikan. Sedangkan secara modern adalah sebagai penyaring limbah, makanan, obat-obatan, bahan untuk pabrik kertas, dan sumber bahan kimia.

Metode: Pengukuran kadar flavonoid teh daun lamun (Enhalus acoroides) dianalisis menggunakan uji anava satu jalur. Penelitian ini dilaksanakan pada tanggal 10 - 18 Juli 2018.

Hasil: Analisis menunjukkan bahwa minuman teh yang berasal dari daun lamun (Enhalus acoroides) yang tua memiliki kadar flavonoid yang tinggi yakni sebesar $0,1623 \%$ sedangkan minuman teh dengan daun lamun yang setengah tua mempunyai kadar flavonoid yang sedang yakni sebesar $0,1263 \%$.

Kesimpulan: Minuman teh yang menggunakan daun lamun (Enhalus acoroides) muda mempunyai kadar flavonoid yang lebih rendah yakni $0.0888 \%$.
\end{abstract}

Kata kunci: Kadar flavonoid, teh, daun lamun Enhalus acoroides, tingkat ketuaan daun. 


\section{PENDAHULUAN}

Lamun (Enhalus acoroides) adalah tumbuhan berbunga (Angiospermae) yang sudah sepenuhnya menyesuaikan diri hidup terbenam di dalam laut. Tumbuhan ini mempunyai beberapa sifat yang memungkinkan hidup di lingkungan laut, yaitu mampu hidup di media air asin, mampu berfungsi normal dalam keadaan terbenam, mempunyai sistem perakaran jangkar yang berkembang baik, mampu melaksanakan penyerbukan dan daur generatif dalam keadaan terbenam. Secara struktural lamun memiliki batang yang terbenam dalam tanah yang disebut rimpang. Rimpang dan akar lamun terbenam di dalam substrat yang membuat lamun dapat berdiri dengan kuat menghadapi arus dan ombak (Dahuri, 2003).

Lamun memiliki perbedaan yang nyata dengan tumbuhan yang hidup terbenam dalam laut lainnya, misalnya makro-algae atau rumput laut (seaweeds). Tanaman lamun memiliki bunga dan buah yang kemudian berkembang menjadi benih. Lamun juga memiliki sistem perakaran yang nyata, dedaunan, sistem transportasi internal untuk gas dan nutrient, serta stomata yang berfungsi dalam pertukaran gas. Akar pada tumbuhan lamun tidak berfungsi penting dalam pengambilan air, karena daun dapat menyerap nutrient secara langsung dari dalam air laut. Lamun tumbuh subur terutama di daerah terbuka pasang surut dan perairan pantai yang dasarnya merupakan lumpur, pasir, kerikil dan patahan karang mati dengan kedalaman sampai empat meter. Lamun yang terdapat di Indonesia terdapat 12 jenis yaitu Cymodocea serrulata, C. rotundata, Enhalus acoroides, Halodule uninervis, $H$. pinifolia, Halophila minor, $H$. ovalis, $H$. decipiens, $H$. spinulosa, Thalassia hemprichii, Syringodium isoetifolium dan Thalassodendron ciliatun (Dahuri, 2003).

Lamun juga sebagai komoditi yang sudah banyak dimanfaatkan oleh masyarakat baik secara modern maupun tradisional. Secara tradisional lamun telah dimanfaatkan untuk kompos dan pupuk, cerutu dan mainan anak-anak, dianyam menjadi keranjang, ada yang dimakan, dan dibuat menjadi jarring ikan. Sedangkan secara modern adalah sebagai penyaring limbah, makanan, obat-obatan, bahan untuk pabrik kertas, dan sumber bahan kimia.

Teh merupakan hasil olahan dari daun Teh (Camellia sinensis) yang digunakan sebagai bahan baku pembuatan minuman. Indonesia minuman teh telah lama dikenal dan digemari masyarakat. Minuman jenis ini digemari karena harganya relatif murah, mudah diperoleh serta menyegarkan.Selain sebagai minuman yang menyegarkan, teh telah lama diyakini memiliki khasiat bagi kesehatan tubuh.Teh memiliki kandungan senyawa aktif yaitu flavonoid yang mampu berperan sebagai antioksidan alami yang menjaga tubuh dari serangan radikal bebas.

Flavonoid termasuk senyawa fenolik yang biasa ditemukan pada batang, daun, bunga, dan buah (Waji dan Andis, 2009). Flavonoid merupakan salah satu senyawa antioksidan yang dapat menghambat penggumpalan keping-keping darah, merangsang produksi nitrit oksidan yang dapat melebarkan (relaksasi) pembuluh darah, dan juga menghambat pertumbuhan sel kanker (Winarsi, 2011).

Flavonoid adalah suatu kelompok senyawa fenol yang terbesar ditemukan di alam. Senyawa-senyawa ini merupakan zat warna merah, ungu, dan biru, dan sebagian zat warna kuning yang ditemukan dalam tumbuh-tumbuhan. Flavonoid mempunyai kerangka dasar karbon yang terdiri dari 15 atom karbon, dimana dua cincin benzene (C6) terikat pada suatu rantai propan (C3) sehingga membentuk suatu susunan C6C3-C6. Susunan ini dapat menghasilkan tiga jenis struktur, yakni 1,3-diarilpropan atau neoflavonoid. Senyawa-senyawa flavonoid terdiri dari beberapa jenis tergantung pada tingkat oksidasi dari rantai propane dari sistem 1,3-diarilpropana. Flavon, flavonol dan antosianidin adalah jenis yang banyak ditemukan dialam sehingga sering disebut sebagai flavonoida utama. Banyaknya senyawa flavonoida ini disebabkan oleh berbagai tingkat hidroksilasi, alkoksilasi atau glikosilasi dari struktur tersebut. Flavonoid merupakan senyawa polar karena memiliki sejumlah gugus hidroksil yang tidak tersubtitusi. Metode ekstraksi yang digunakan dalam penelitian ini yaitu maserasi. Daun lamun yang diambil untuk penelitian yaitu daun yang masih muda, setengah tua dan daun tua. Adapun ciri-ciri dari daun lamun muda 
yaitu berwarna hijau muda, daun setengah tua berwarna hijau, dan daun tua berwarna hijau tua. Penelitian Hernani dan Rahmawati (2009), tentang pengeringan tanaman, pengoven pada daun dengan $60^{\circ} \mathrm{C}$. Suhu pengeringan dengan oven mempengaruhi kualitas daun kering dan kandungan senyawa aktif daun tersebut.

Tanaman lamun merupakan salah satu tanaman yang memiliki manfaat sebagai obat tradisional (Dalimartha, 2008). Salah satu bentuk yang paling mudah dan paling umum untuk mengkonsumsi daun alpukat adalah dengan menjadikannya sebagai teh. Daun lamun diketahui memiliki aktivitas antioksidan yang tinggi dan dapat membantu mencegah atau memperlambat stress oksidatif yang berhubungan dengan berbagai penyakit (Owolabi et al., 2010). Daun lamun (Perseaamericana Mill.) mengandung senyawa flavonoid, tanin, kuinon, saponin, dan, steroid/triterpenoid (Maryati et al., 2007).

Kualitas teh dipengaruhi oleh ketuaan daun dan metode pengolahannya. Ketuaandaun berpengaruh pada kandungan dan jenis flavonoid. Pada daun teh (Camellia sinensis), kadar flavonoid daun muda lebih tinggi daripada kadar flavonoid daun tua (Izzreen dan Fadzelly, 2013), sedangkan menurut Mu'nisa et al (2011), daun lamun tua memiliki kadar flavonoid lebih tinggi dibandingkan daun muda. Signifikansi tingkat perbedaannya sampai sekarang belum diketahui (Pambayun et al., 2007), sedangkan proses pengolahan juga menentukan kualitas teh. Metode pengolahan yang berbeda dapat mempengaruhi karakteristik fisik dari teh dan air seduhannya, serta kandungan antioksidan dari teh tersebut.

\section{MATERI DAN METODE PENELITIAN}

Jenis Penelitian ini menggunakan penelitian Ekperimental Laboratorium..
Penelitian ini dilakukan dengan, Pengambilan sampel daun lamun (Enhalus acoroides) di Desa Suli, Pembuatan teh daun lamun di laboratorium Biologi Dasar FKIP Unpattii, dan Pengujian kadar flavonoid di Laboratorium Kimia Dasar FMIPA Unpatti, Penelitian ini dilaksanakan pada tanggal 10 - 18 juli 2018.

Subjek dalam penelitian ini Subjek pada penelitian ini adalah daun lamun (Enhalus acoroides). Objek pada penelitian ini adalah teh dari daun lamun (Enhalus acoroides) muda (hijau muda), setengah tua (hijau) dan tua (hijau tua). Variabel Bebas: yang menjadi variabel bebas dalam penelitian ini adalah tingkat ketuaan daun lamun: daun muda, daun setengah tua dan daun tua. Penelitian ini menggunakan Rancangan Acak Lengkap (RAL) adalah dengan 3 perlakuan dan tiga kali pengulangan.

Data hasil identifikasi akan dianalisis secara deskriptif dengan bantuan tabel dan grafik. Analisis data ini dilakukan dengan menggunakan rumus persamaan regresi linier.

$$
\begin{aligned}
& Y=a x+b \\
& \text { atau } \\
& X=y-a / b
\end{aligned}
$$

\section{HASIL DAN PEMBAHASAN}

Penelitian pengukuran kadar flavonoid pada minuman teh daun lamun Enhalus acoroides telah dilakukan. Hasil pengukuran menunjukkan perbedaan di antara variasi tingkat ketuaan daun. Ratarata hasil pengukuran kadar flavonoid berdasarkan perlakuan dapat dilihat pada Tabel 1 dan Grafik 1 berikut ini. 
Tabel 1. Hasil Pengukuran Flavonoid Teh Daun Lamun

\begin{tabular}{ccccccl}
\hline No & \multicolumn{1}{c}{ Kode Sampel } & $\begin{array}{c}\text { Berat } \\
\text { Sampel }\end{array}$ & Abs & C & $\begin{array}{c}\text { Berat } \\
\text { Flavonoid }\end{array}$ & $\begin{array}{c}\text { Kadar } \\
\text { Flavonoid }\end{array}$ \\
\hline 1 & Daun muda U1 & 20,1092 & 0,1560 & 4,3 & 17,2 & 0,0855 \\
2 & Daun muda U2 & 20,1075 & 0,1610 & 4,5 & 18,0 & 0,0895 \\
3 & Daun muda U3 & 20.1107 & 0,1670 & 4,6 & 18,4 & 0,0914 \\
4 & Daun setengah tua U1 & 20,1580 & 0,2320 & 6,3 & 27,6 & $0,2664 / 3=0,888$ \\
5 & Daun setengah tua U2 & 20,1397 & 0,2260 & 6,1 & 24,4 & 0,1369 \\
6 & Daun setengah tua U3 & 20,1487 & 0,2230 & 6,1 & 24,4 & 0,1210 \\
7 & Daun tua U1 & 20,2045 & 0,2960 & 8,2 & 32,8 & $0,379 / 3=0,1263$ \\
8 & Daun tua U2 & 20,1987 & 0,2940 & 8,1 & 32,4 & 0,1623 \\
9 & Daun tua U3 & 20,2016 & 0,3010 & 8,3 & 33,2 & 0,1643 \\
\hline
\end{tabular}

Tabel 1, di atas menunjukkan bahwa minuman teh yang berasal dari daun lamun Enhalus acoroides yang lebih tua menghasilkan kadar flavonoid tertinggi dibandingkan dengan minuman teh dari daun lamun muda dan setengah tua. Ratarata pengujian kadar flavonoid kemudian divisualisasikan pada Grafik di bawah ini.

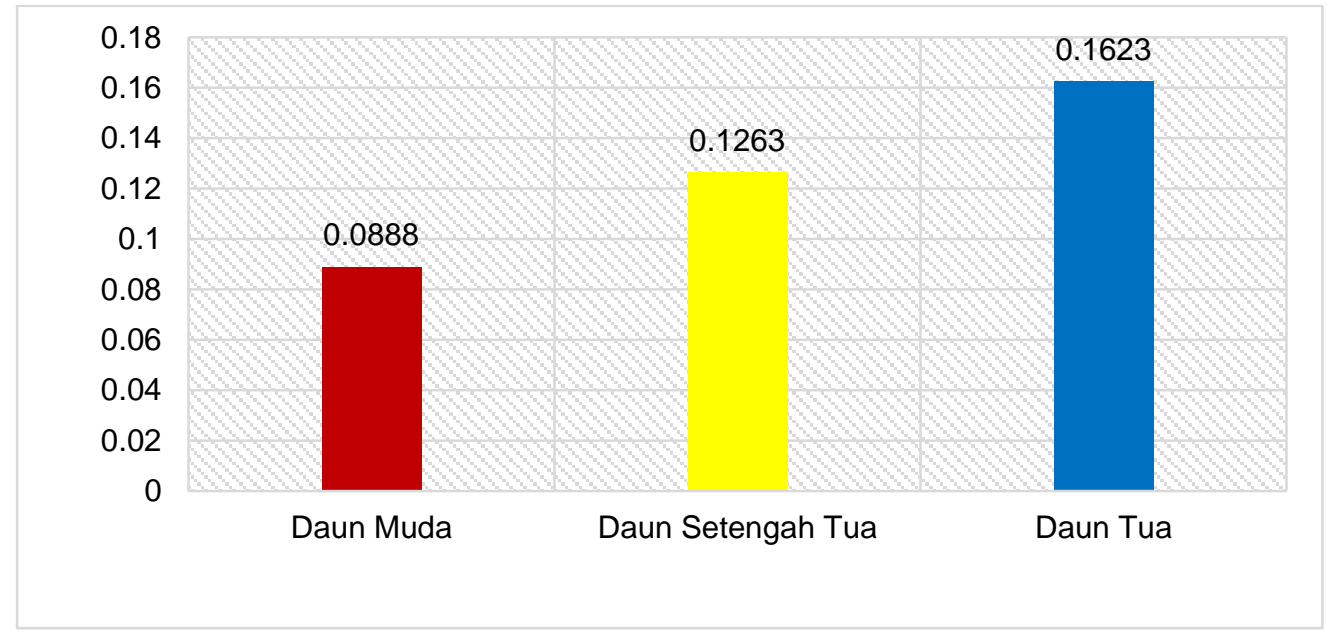

\section{Grafik 1. Rata-Rata Kadar Flavonoid Teh Daun Lamun.}

Visualisasi grafik 1 juga menunjukkan bahwa semakin tua daun lamun Enhalus acoroides, maka kadar flavonoid teh daun lamun juga tinggi. Apabila diurut-urutkan maka, kadar flavonoid teh daun lamun yang lebih tinggi adalah apabila menggunakan daun lamun tua, daun lamun setengah tua, dan yang paling rendah adalah daun lamun Enhalus acoroidesyang masih muda.

Data pengukuran kadar flavonoid teh daun lamun Enhalus acoroides kemudian dianalisis menggunakan uji anava satu jalur. Uji anava digunakan untuk mengetahui pengaruh tingkat ketuaan daun lamun Enhalus acoroides terhadap kadar flavonoid teh daun lamun. Namun sebelum melakukan uji anava dilakukan uji prasyarat normalitas dan homogenitas. Uji normalitas menggunakan uji Shapiro Wilk. Berdasarkan uji normalitas diketahui bahwa signifikan 0.134> $\alpha=0.050$.

Berdasarkan uji homogenitas diketahui bahwa signifikan $0.077>\alpha=0.050$, artinya data berasal dari populasi yang homogen. Oleh karena data pengukuran kadar flavonoid teh daun lamun normal dan homogen, maka uji anava satu jalur dapat dilanjutkan uji anava satu jalur ditunjukan pada Tabel 2 berikut ini. 
Biopendix, Volume 5, Nomor 1, Oktober 2018, hlm. 01-07

Tabel 2. Hasil Uji Anava Pengukuran Kadar Flavonoid Teh Daun Lamun

\begin{tabular}{llcccr}
\hline Sumber & $\begin{array}{l}\text { Jumlah } \\
\text { Kuadrat }\end{array}$ & Df & $\begin{array}{c}\text { Rata-rata } \\
\text { kuadrat }\end{array}$ & F & Sig. \\
\hline $\begin{array}{l}\text { Between } \\
\text { Groups }\end{array}$ & .008 & 2 & .004 & 125.939 .000 \\
$\begin{array}{l}\text { Within } \\
\text { Groups }\end{array}$ & .000 & 6 & .000 & & \\
Total & .008 & 8 & & & \\
\hline
\end{tabular}

Hasil analisis varians pada tabel 2 di atas menunjukkan bahwa variasi tingkat ketuaan daun memiliki nilai signifikansi $0,000<\alpha=0,05$, sehingga hipotesis penelitian diterima, artinya terdapat pengaruh variasi tingkat ketuaan daun terhadap kadar flavonoid teh daun lamun
Enhalus acoroides. Selanjutnya dilakukan uji LSD (Least Significance difference) dengan taraf kepercayaan $5 \%$ untuk menentukan perbedaan rata-rata variasi tingkat ketuaan daun lamun Enhalus acoroides. Hasil uji LSD ditunjukkan pada Tabel 3 di bawah ini.

\section{Tabel 3. Hasil Uji LSD Kadar Flavonoid Teh Daun Lamun}

\begin{tabular}{llll}
\hline Variasi Tingkat Ketuaan Daun & Rerata & Notasi \\
\hline Teh Daun Tua & 0.1623 & a & \\
Teh Daun Setengah Tua & 0.1263 & b \\
Teh Daun Muda & 0.0888 & c \\
\hline
\end{tabular}

Berdasarkan tabel 3 di atas diketahui bahwa terdapat perbedaan notasi huruf antara variasi tingkat ketuaan daun. Teh yang berasal dari daun lamun tua mempunyai kadar flavonoid tertinggi dilambangkan dengan notasi a; teh yang berasal dari daun setengah tua dilambangkan notasi $b$; serta teh yang berasal dari daun lamun muda mempunyai kadar flavonoid terendah.

\section{Pembahasan}

Beberapa penelitian telah dilakukan untuk menganalisis kadar flavonoid pada daun lamun Enhalus acoroides. Penelitian oleh Rahakbauw (2016) menunjukkan bahwa senyawa flavonoid daun lamun Enhalus acoroides sebesar 3,5697\%. Sedangkan, penelitian Timisela (2016) melaporkan bahwa, rata-rata kadar flavonoid daun lamun Enhalus acoroides tertinggi terdapat pada sampel Desa Rutong yaitu $0.1157 \%$, sedangkan rata-rata kadar flavonoid daun lamun Enhalus acoroidesyang lebih rendah terdapat pada sampel Desa Galala yaitu 0.01925\%. Penelitian tersebut menunjukkan bahwa daun lamun Enhalus acoroides memiliki kandungan flavonoid yang baik.

Selain tanaman Camellia sinensis, potensi tanaman lamun Enhalus acoroides sebaga isumber flavonoid juga dapat dikembangkan menjadi minuman teh. Hasil analisis deskriptif pada Tabel 1 dan Grafik 1 menunjukkan bahwa minuman teh yang berasal dari daun lamun Enhalus acoroides yang tua memiliki kadar flavonoid yang tinggi yakni sebesar $0.1623 \%$; sedangkan minuman teh dengan daun lamun yang setengah tua mempunyai kadar flavonoid yang sedang yakni sebesar $0.1263 \%$. Minuman teh yang menggunakan daun muda mempunyai kadar flavonoid yang lebih rendah yakni $0.0888 \%$. Lebih lanjut analisis ANAVA satu jalur pada Tabel 2 menunjukkan pengaruh tingkat ketuaan daun lamun Enhalus acoroides terhadap kadar flavonoid minuman teh tersebut. Penelitian Felicia, dkk. (2015) menunjukkan bahwa teh yang terbuat dari daun alpukat tua memiliki nilai rata-rata total flavonoid lebih tinggi dibandingkan dengan daun alpukat muda. Hasil yang sama juga dilaporkan oleh Mu'nisa et al, (2011), bahwa ekstrak daun sukun tua memiliki 
kadar flavonoid lebih tinggi dibanding daun sukun muda.

Hasil penelitian menunjukkan bahwa semakin tua daun, maka kandungan flavonoid daun semakin tinggi. Menurut Farhoosh et al, (2007) faktor yang mempengaruhi kadar total flavonoid dalam daun adalah morfologi dan bertambahnya usia daun, yang akan mempengaruhi metabolit sekunder dan senyawa bioaktif yang dihasilkan. Bhakta dan Ganjewala (2009) menambahkan bahwa variasi kandungan flavonoid disebabkan karena perbedaan usia perkembangan daun yang terjadi pada lokasi daun yang berbeda. Oleh karena itu, teh yang berasal dari daun lamun tua memiliki kadar flavonoid yang lebih tinggi dibandingkan dengan teh yang berasal dari daun lamun setengah tua dan daun muda.

Tabel 3 uji lanjut menunjukkan perbedaan yang sangat nyata dari ketiga variasi daun lamun Enhalus acoroides tersebut. Perbedaan tingkat ketuaan daun tersebut ditunjukkan melalui notasi huruf yang berbeda satu dengan yang laun. Teh daun lamun yang tua ditandai dengan notasi a, daun setengah tua dengan notasi b, dan daun muda ditandai notasi c. Adanya perbedaan flavonoid disebabkan umur daun secara morfologi dan fisiologi yang berbeda. Waji (2009), melaporkan bahwa daun yang tua (pada penelitiannya disebut daun matang) memiliki kemampuan optimum untuk menghasilkan metabolit sekunder sehingga kadar flavonoid juga tinggi.

Tumbuhan lamun merupakan salah satu jenis tumbuhan yang hidup pada teritorial laut yang tenggelam saat air pasang, sedangkan pada saat air surut maka daun lamun akan terkena sinar matahari secara langsung. Oleh karena itu, bagi tumbuhan lamun sinar matahari merupakan salah satu faktor cekaman lingkungan. Cekaman lingkungan ini mengakibatkan metabolit sekunder disintesis lebih tinggi pada daun yang tingkat perkembangannya lebih tua. Ibrahim dan Jaafar (2012) berpendapat bahwa paparan sinar matahari akan meningkatkan produksi metabolit sekunder. Dalam hal ini flavonoid pada tumbuhan lamun Enhalus acoroides juga merupakan salah satu metabolit sekunder. Lebih lanjut penelitian
Li dan Kubota melaporkan bahwa penggunaan sinar LED sebagai pengganti sinar matahari dapat meningkatkan konsentrasi fenolik pada daun selada. Hal ini membuktikan bahwa daun lamun tua yang telah memiliki tingkat kematangan daun lebih sempurna sehingga menghasilkan laju fotosintesis yang tinggi, seiring dengan laju fotosintesis maka metabolit sekunder yang terbentuk juga lebih banyak dibandingkan dengan daun setengah tua dan daun muda. Oleh karena itu, minuman teh yang terbuat dari daun lamun Enhalus acoroides yang tua memiliki kadar flavonoid yang lebih tinggi.

\section{KESIMPULAN}

Berdasarkan penelitian yang di lakukan, maka dapat disimpulkan bahwa terdapat perbedaan kadar flavonoid pada tingkat ketuaan daun lamun (Enhalus acoroides). Rata-rata kadar flavonoid pada sampel daun lamun muda adalah0.0888\%, rata-rata kadar flavonoid pada sampel daun lamun setengah tua adalah $0.1263 \%$ dan rata-rata kadar flavonoid pada sampel daun lamun tua adalah $0.1623 \%$.

\section{DAFTAR PUSTAKA}

Bhakta, D dan D.J. Ganjewala. 2009. Tea, Kombucha, and Health: A Review. Journal of Food Research International, 33, 409-421.

Dahuri R. 2003. Keanekaragaman Hayati Laut Aset Pembangunan Berkelanjutan Indonesia. Jakarta: PT Gramedia Pustaka Utama.

Dalimartha, S. 2008. Atlas Tumbuhan Obat Indonesia Jilid 3. Perpustakaan Nasional RI, Jakarta.

Farhoosh, R., G. A. Golmovahhed, and M. H.H. Khodaparast. 2007. Antioxidant Activity of Various Extracts of Old TeaLeaves and Black Tea Wastes (Camellia sinensis L.). Food

Felicia, N., I Wayan Rai Widarta, Ni Luh Ari Yusasrini. 2015. Pengaruh Ketuaan Daun dan Metode Pengolahan terhadap Aktivitas Antioksidan dan Karakteristik Sensoris Teh Herbal Bubuk Daun Alpukat (Persea americana Mill.). Artikel Publikasi. Vol 5 No 2: JURNAL ITEPA. 
Hernani dan Rahmawati Nurdjanah. 2009. Aspek Pengeringan Dalam Mempertahankan Kandungan Metabolit Sekunder Pada Tanaman Obat. JurnalPerkembangan Teknologi Tro. Vol. 21 No. 2, Desember 2009: 33-39.

Ibrahim, M.H. dan H.Z. Jaafar. 2012. Primary, Secondary Metabolites, $\mathrm{H}_{2} \mathrm{O}_{2}$, Malondialdehyde and Photosynthetic Response of Orthosiphon stimaneus Bent. to Different Irradiance. Molecules. 17: 1159-1176.

Izzreen, N.Q., dan M. Fadzelly. 2013. Phytochemicals and Antioxidant Properties of Different Parts of Camellia sinensis leaves from Sabah TeaPlantation in Sabah, Malaysia. IFJR 20(1):307-312.

Maryati, S.I. Fidrianny, dan K. Ruslan. 2007. Telaah Kandungan Kimia Daun Alpukat (Persea americana Mill.). Skripsi S1. Sekolah Farmasi, Institut Teknologi Bandung.

Mu'nisa, A.H. Pagarra, dan A. Muflihunna. 2011. Uji Kapasitas Antioksidan Ekstrak Daun Sukun dan Flavanoid. Skripsi S1. Tidak dipublikasikan. Fakultas Matematika dan IImu Pengetahuan Alam, Universitas Negeri Makassar.
Owolabi, M.A., Coker dan S.I. Jaja. 2010. Bioactivity of the phytoconstituents of the leaves of Persea americana. Journal of Medicinal Plants Research 4(12):1130-1135.

Pambayun, R., M. Gardjito, S. Sudarmadji, K. Rahayu. 2007. Kandungan Fenolik Ekstrak Daun Gambir (Uncaria gambir Roxb) dan Aktivitas Antibakterinya. AGRITECH Vol. 27, No. 2.

Rahakbauw, I.D. 2016. Analisis Senyawa Flavonoid Daun Lamun Enhalus acoroides di Perairan Pantai Desa Waai Kabupaten Maluku Tengah, Skripsi. Tidak Dipublikasikan. FKIP Pendidikan Biolog UNPATTI: Ambon.

Timisela, P.P., 2015. Identifikasi dan Analisis Flavonoid Daun Lamun Enhalus acoroides Pada Perairan Pantai Desa Galala dan Rutong, Skripsi. Tidak Dipublikasikan. FKIP Pendidikan Biologi UNPATTI: Ambon.

Waji A.R, Andis S. 2009. Flavonoid (Quercetin). Makasar: Fakultas MIPA Universitas Hasanuddin.

Winarsi, Hery. 2011. Antioksidan Alami dan Radikal Bebas. Yogyakarta: Kanisi. 